\title{
Removal of Nitrogen and Phosphorus from Domestic Wastewater by Electrocoagulation: Application of Multilevel Factorial Design
}

\author{
Edwar Aguilar-Ascon' \\ 1 Instituto de Investigación Científica (IDIC), Universidad de Lima, Avenida Javier Prado Este No. 4600, 33, Lima, \\ Peru \\ e-mail: eaguilaa@ulima.edu.pe
}

\begin{abstract}
The main objective of this investigation was to evaluate the efficiency of electrocoagulation in eliminating nitrogen and phosphorous from domestic wastewater and to determine the main operating parameters affecting the process. Accordingly, an acrylic reactor and aluminum (cathode) and iron (anode) electrodes were used. The tests were performed based on a multilevel factorial experimental design, considering current intensity, treatment time, and $\mathrm{pH}$ as factors. The design response variables were the percentage of nitrogen and phosphorous removal. In the case of phosphorus, the removal rates of up to $99 \%$ were reached after 40 minutes of treatment with current intensities of 3 amps and at a modified $\mathrm{pH}$ of 6 . The nitrogen removal was up to $27 \%$ with a treatment time of 40 minutes, 3 amps, and a pH of 6 . A statistical analysis revealed that $\mathrm{pH}$ did not have a significant effect on the nitrogen removal process, whereas in the phosphorus removal, the three factors influenced the process at a confidence level of 0.05 . The results indicate that the electrocoagulation process in this type of water is very efficient in the removal of phosphorus, whereas for nitrogen, the efficiency decreases noticeably. However, electrocoagulation has an advantage over other conventional treatment technologies, because it does not require additional treatment units to remove phosphorus.
\end{abstract}

Keywords: electrode, electrocoagulation, nitrogen, phosphorous, domestic wastewater.

\section{INTRODUCTION}

A large amount of domestic wastewater is generated in Peru. It is treated to remove the organic matter and pollutants present in the water. This is accomplished using the biological treatment processes such as activated sludge, which are highly efficient but cannot remove nitrogen or phosphorous. Therefore, to achieve this, additional treatment units have to be added, which hinders operation and increases the treatment costs.

The discharge of nutrient-rich wastewater into water bodies can lead to eutrophication, which is the fertilization process of the aquatic vegetation in natural waters with nitrogen and phosphorus [Muñoz, 2014]. This process leads to an increase in the algal population and the deterioration of the physicochemical characteristics of the water; besides, it inhibits photosynthesis, causing a decrease in the amount of dissolved oxygen in water bodies and the generation of a toxic environment for the aquatic organisms. [Muñoz, 2014; Rahimi, 2011].

Considering the abovementioned problems, it is therefore very important to seek alternative treatments for the removal of nutrients. The most used methods are chemical precipitation and biological processes. However, other technologies such as electrocoagulation are also being investigated.

One such study was conducted by [Xiangdong Li, 2011], which reported the ammonia nitrogen removal values of $38.5 \%$ in leachate from a landfill. Furthermore, [Kuokkanen, 2015] applied electrocoagulation for the removal of phosphate from mining industry wastewater using hybrid aluminum and iron electrodes with an efficiency greater than $90 \%$. Similarly, [Thapa, 2015] used this process to mitigate the contamination or pollution with effluents from feedlots 
with high nitrogen and phosphorous content, where the phosphorus removal exceeded 95\%, while the nitrogen removal varied from $25 \%$ to $60 \%$. [Taufer, 2016] reported a total phosphorous removal efficiency of $95.6 \%$ and total nitrogen removal efficiency of $71.8 \%$ from the dairy industry wastewater using aluminum electrodes. Furthermore, two studies on domestic wastewater treatment can be mentioned: the first conducted by [Omwene, 2013] who reported a 99\% removal rate of total phosphorus with hybrid aluminum andiron anodes, while [Tian, 2018] reported 98\% phosphate removal with titanium electrodes.

Electrocoagulation is an electrochemical process that involves the generation of coagulants by the DC voltage applied to a sacrificial electrode where $\mathrm{Al}^{3+}$ or $\mathrm{Fe}^{+2}$ ions are produced. This process hydrolyzes and generates the coagulant that allows the destabilization of colloidal particles present in the water [Piña, 2011]. Ions are attracted to colloidal particles, which neutralize their charge and enable coagulation. The hydrogen gas is generated at the cathode, which interacts with the particles that cause flocculation, thereby causing the contaminants to rise to the surface to be removed [Elnenay, 2016]. The metal ions generated are hydrolyzed in the electrocoagulation reactor, mainly at the $\mathrm{pH}$ values in the range of 7-9 to produce various metal substances, such as complex and neutral hydroxides $\mathrm{M}(\mathrm{OH})_{3}[\mathrm{Can}$, 2014]. Aluminum and iron are the most used materials as anode and cathode, respectively. [Chen, 2014]. These generate the following reactions:

For the aluminum anode:

$$
A l-3 e \rightarrow A l^{3+}
$$

under alkaline conditions

$$
\mathrm{Al}^{3+}+3 \mathrm{OH}^{-} \rightarrow \mathrm{Al}(\mathrm{OH})_{3}
$$

under acidic conditions

$$
\mathrm{Al}^{3+}+3 \mathrm{H}_{2} \mathrm{O} \rightarrow \mathrm{Al}(\mathrm{OH})_{3}+3 \mathrm{H}^{+}
$$

For the iron anode:

$$
\mathrm{Fe}-2 e \rightarrow \mathrm{Fe}^{2+}
$$

under alkaline conditions

$$
\mathrm{Fe}^{2+}+3 \mathrm{OH}^{-} \rightarrow \mathrm{Fe}(\mathrm{OH})_{2}
$$

under acidic conditions

$$
4 \mathrm{Fe}^{2+}+\mathrm{O}_{2}+2 \mathrm{H}_{2} \mathrm{O} \rightarrow 4 \mathrm{Fe}^{3+}+4 \mathrm{OH}^{-}
$$

In addition, there is the oxygen evolution reaction

$$
2 \mathrm{H}_{2} \mathrm{O}-4 e \rightarrow \mathrm{O}_{2}+4 \mathrm{H}^{+}
$$

The reaction at the cathode is

$$
2 \mathrm{H}_{2} \mathrm{O}+2 e \rightarrow \mathrm{H}_{2}+2 \mathrm{OH}^{-}
$$

Few studies have been conducted with this type of water; therefore, the main objective of this study was to evaluate the efficiency of the nitrogen and phosphorus removal from domestic wastewater by applying the electrocoagulation process and determine how its main operating parameters (current intensity, treatment time, and $\mathrm{pH})$ influence the process.

\section{MATERIALS AND METHODS}

\section{Wastewater characteristics}

One of the main priorities of this study was the use of real domestic wastewater collected in a treatment plant, because it exhibits completely different conditions than the synthetic water prepared in the laboratory. Accordingly, the treatment plant of the Research Center for the Treatment of Wastewater and Hazardous Waste of the Universidad Nacional de Ingeniería [National Engineering University] (Citrar-UNI) was chosen. This plant receives domestic effluents from an urban area in the city of Lima. Table 1 gives the values obtained from the initial characterization of the effluent. These values vary 24 hours a day, owing to the periods of discharge from the population.

Table 1. Physicochemical and biological analysis of the effluent

\begin{tabular}{|l|c|}
\hline \multicolumn{1}{|c|}{ Parameter } & Result \\
\hline Nitrogen $(\mathrm{mg} / \mathrm{L})$ & 62.63 \\
\hline Phosphorus $(\mathrm{mg} / \mathrm{L})$ & 8.06 \\
\hline COD $(\mathrm{mg} / \mathrm{L})$ & 779 \\
\hline $\mathrm{BOD}_{5}(\mathrm{mg} / \mathrm{L})$ & 209 \\
\hline Conductivity $(\mu \mathrm{S} / \mathrm{cm})$ & 1290 \\
\hline $\mathrm{pH}$ & 7.5 \\
\hline Total suspended solids $(\mathrm{mg} / \mathrm{L})$ & 348 \\
\hline Oil and fat $(\mathrm{mg} / \mathrm{L})$ & 104.7 \\
\hline Nitrates & 0.199 \\
\hline Fecal coliforms $(\mathrm{MPN} / 100 \mathrm{ml})$ & 2800000 \\
\hline
\end{tabular}




\section{Electrocoagulation equipment}

A batch-type electrocoagulation acrylic reactor was used. It was $20-\mathrm{cm}$ wide, 20 -cm long, and $25-\mathrm{cm}$ high, with a capacity to treat 10 liters of wastewater. Four aluminum plates were used as a sacrificial electrode on the anode and four iron plates, $10-\mathrm{cm}$ wide, $10-\mathrm{cm}$ long, and $0.01 \mathrm{~cm}$ thick, with a surface area per plate of $100 \mathrm{~cm}^{2}$ were used on the cathode. Current was supplied from a power source with a capacity of 0-12 amps and an adjustable voltage of $0-30$ volts (Figure 1).

\section{Experimental tests}

The experimental design given in Table 3 considers three test stages: Stage 1 (natural $\mathrm{pH}$ 7.5), Stage $2(\mathrm{pH} \mathrm{9)}$, and Stage $3(\mathrm{pH} \mathrm{6)}$. Two intensities of electric current, i.e., 1 and 3 amps, were used in each stage and the water samples were taken at $0,10,20,30$, and 40 minutes of the treatment. Sulfuric acid at a concentration of $1 \mathrm{~N}$ was used to modify the $\mathrm{pH}$ of the water. The measurements of $\mathrm{pH}$, conductivity, and temperature were conducted in the field with an OAKTON PCS 35 multiparameter. In order to realize an effluent under real conditions, the tests were conducted with electrocoagulation treatment in the field, taking 24 samples of the treated water to measure the final nitrogen and phosphorous concentrations. For nitrogen determination, the analysis method SMEWW-APHA-AWWA-WEF Part 4500-P J: 2012 was used; 22nd Ed. Persulfate Method for Simultaneous Determination of Total Nitrogen, whereas for total phosphorus, the method SMEWW-APHA-AWWA-WEF Part 4500-P B Item 5, E: 2012; 22nd Ed. Phosphorus. Sample Preparation 5 was used. In order to determine the nitrogen and phosphorous removal percentages, equation 9 was used.

For nitrogen and phosphorus:

$$
\% Y=\left(\frac{C_{i}-C_{f}}{C_{f}}\right)
$$

where: \%Y: nitrogen and phosphorous removal percentage.

$C_{i}:$ Initial nitrogen and phosphorus concentration

$C_{f}$ Final nitrogen and phosphorous concentration

\section{Experimental design}

A completely randomized three-factor design with several levels was used in this research. The factors considered in the design were the current intensity $\left(\mathrm{x}_{1}\right)$, treatment time $\left(\mathrm{x}_{2}\right)$, and $\mathrm{pH}\left(\mathrm{x}_{3}\right)$, while the percentage of the nitrogen and phosphorous removal were the response variables $\left(\mathrm{y}_{1}\right)$ and $\left(\mathrm{y}_{2}\right)$ (see Table 2). This allowed us to determine the individual effect and the interaction between the factors on the response variable ( $\%$ removal of nitrogen and phosphorous) and to identify their significance in the process. The Statgraphics Centurion XVI software was used for statistical analysis. An analysis of variance (ANOVA) was obtained (table) with a confidence level of $95 \%$. In addition, the regression coefficients of the generalized second-order polynomial and the

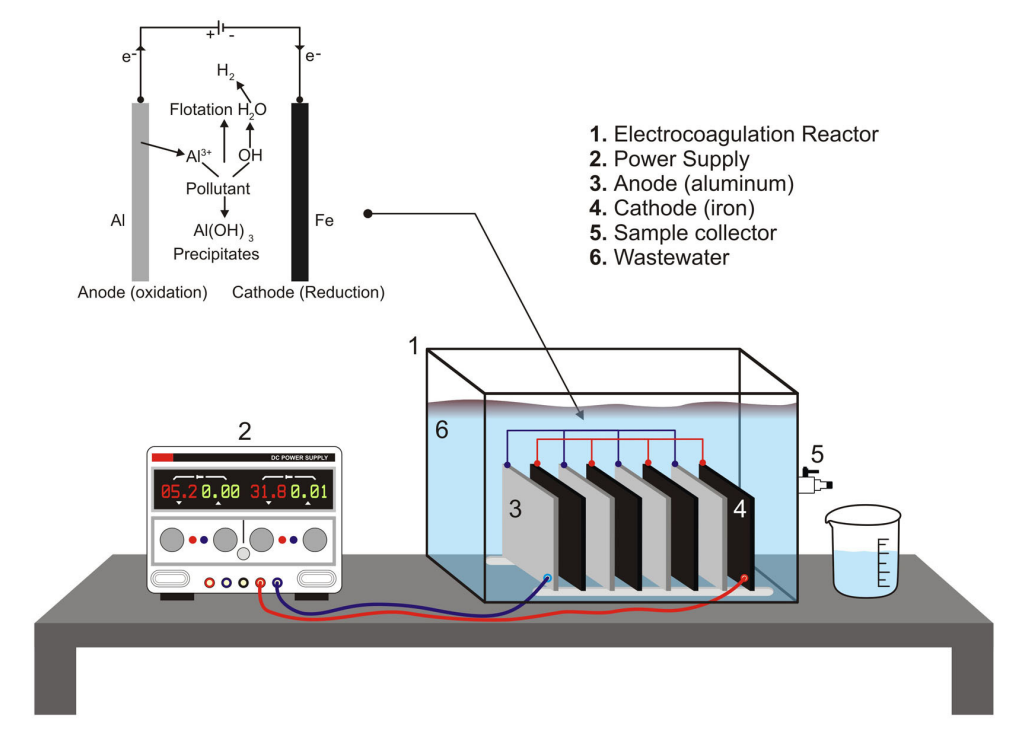

Figure 1. Schematic of the electrocoagulation reactor 
Table 2. Experimental design factors and levels for nitrogen and phosphorus

\begin{tabular}{|c|c|c|c|c|}
\hline Factors & \multicolumn{4}{|c|}{ Levels } \\
\hline $\mathrm{x}_{1}:$ Current intensity $(\mathrm{A})$ & \multicolumn{2}{|c|}{1} & \multicolumn{2}{|c|}{3} \\
\hline$x_{2}:$ Time $(\min )$ & 10 & 20 & 30 & 40 \\
\hline $\mathrm{x}_{3} \cdot \mathrm{pH}$ & \multicolumn{2}{|c|}{6} & \multicolumn{2}{|c|}{9} \\
\hline
\end{tabular}

response surface graphs were obtained. Equation 10 gives the statistical model used in the analysis.

$$
\begin{aligned}
y_{i j k l} & =\mu+\alpha_{i}+\beta_{j}+\gamma_{k}+(\alpha \beta)_{i j}+ \\
& +(\alpha \gamma)_{i k}+(\beta \gamma)_{j k}+\varepsilon_{i j k l}
\end{aligned}
$$

where: $y_{i j k} l-$ the observation of nitrogen and phosphorus removal percentage

$\mu$ - median nitrogen and phosphorus removal percentage

$\alpha_{i}, \beta_{j}, \gamma_{k}-$ effect of the current intensity factor, time, and $\mathrm{pH}$

$(\alpha \beta)_{i j},(\alpha \gamma)_{i k},(\beta \gamma)_{i k}-$ effects of interaction of factors.

\section{RESULTS AND DISCUSSION}

\section{Influence of retention time}

The pollutant removal efficiency increases along with the electrolysis time, but beyond an optimal electrolysis time, this removal efficiency becomes constant [Khandegar, 2013]. Figures 2 and 3 show the efficiency of the phosphorous and nitrogen removal, which increases with the treatment time. However, after 30 minutes, the efficiencies remain practically constant, which is important considering the treatment costs. Long treatment periods cause high consumption of energy and electrodes. [Kobya, 2006]. In the case of phosphorus, after 30 minutes, very high removal values were reached, which varied from $98 \%$ to $99 \%$ depending on different $\mathrm{pH}$ conditions. This coincides with the results of Omwene who reported 97\% efficiency in reducing phosphates at different current intensities after 30 minutes. However, the removal of total nitrogen was much lower and the highest efficiencies were reached after 40 minutes of retention, with a value of $23 \%$. In another study, Orssatto indicated that after 30 minutes of treatment, $67.15 \%$ efficiency of total nitrogen removal was achieved. Emamjomeh also reported that after 40 minutes of treatment, $93 \%$ efficiency of nitrate removal was reached.

\section{Influence of current intensity}

Current intensity has an important effect on the electrocoagulation process. In the case of nitrogen, it can be observed in Figures 2a, 2b, and $2 \mathrm{c}$ that there is a lesser influence of current intensity than for phosphorus. The highest efficiency of $27 \%$ removal was obtained at 3 amps after 30 minutes of treatment and with the $\mathrm{pH}$ of 6 . These values are similar to those reported by Inan, who achieved the nitrogen removal efficiency of $21 \%$ in synthetic wastewater.

Figures $3 a, 3 b$, and $3 c$ show that at 3 amps, the best results are obtained for the phosphorus removal. The values of $98 \%$ and $99 \%$ were reached after 30 minutes. However, at $1 \mathrm{amp}$, an equal efficiency was achieved but in a longer time. Similar values were reported by Zhang, who achieved the phosphorus removal efficiency of $96.4 \%$. In addition, Omwene reported an efficiency greater than $99 \%$ with aluminum electrodes and a current density of $20 \mathrm{~A} / \mathrm{m}^{2}$.

Current intensity accelerates the process at the beginning. During the first 20 minutes, an important difference in the removal percentages was observed. This matches with Attour's proposal (2014) who indicated that the kinetics is very sensitive to this parameter and the treatment time is faster when the power density is higher. Actually, time and current intensity are closely linked to each other. Furthermore, the current intensity generates a rapid production of small hydrogen bubbles that facilitate the floating of the pollutants [Attour et al., 2014]. Likewise, it is known that the amount of anodic solution of aluminum increases along with the current intensity, which leads to better coagulation and allows the removal of contaminants. It is known that using very high values of current intensity in the electrocoagulation process can cause a decrease in its efficiency owing to the production of oxygen and the passivation of aluminum electrodes [Piña et al., 2011]. The formation of a passive oxide film is one of the problems caused by the use of aluminum as a metallic electrode [Mouedhen, 2008]. The results reveal various options as optimal operating parameters. However, it must be taken into account that with lower amperages, high removal rates can be achieved at a lower cost. 


\section{Influence of $\mathrm{pH}$}

One of the most important factors that affect the performance of the electrocoagulation process, directly influencing the efficiency of the removal of contaminants, is the initial $\mathrm{pH}$ [Bouamra, 2012]. The $\mathrm{pH}$ of water directly affects the solubility of metal hydroxides [Piña et al., 2011] and consequently, the formation of colloidal particles on the anode surface. The $\mathrm{Al}^{3}+$ cations predominate at low $\mathrm{pH}, \mathrm{Al}(\mathrm{OH})_{4}-$ aluminates predominate at a $\mathrm{pH}$ above 10 , and insoluble $\mathrm{Al}(\mathrm{OH})_{3}$ hydroxides predominate at intermediate or neutral pH. [Yehya, 2014].

The results indicate that the difference between the phosphorus removal efficiencies at a $\mathrm{pH}$ of $6,7.5$, and 9 is minimal. In the beginning, it was observed that the variation of this parameter accelerated the process, but after 30 minutes of treatment, they became practically the same

a)

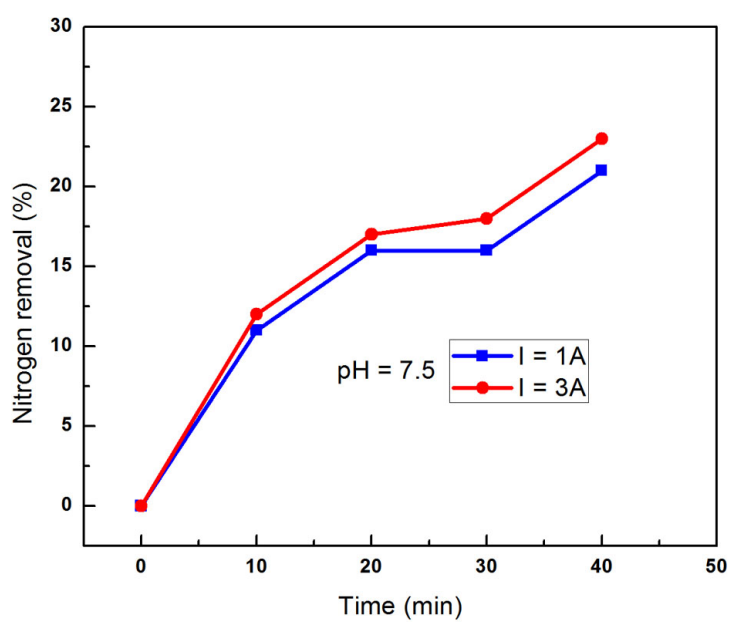

and reached between $98 \%$ and $99 \%$, as shown in Figures 2a, 2b, and 2c. This is similar to what was found by Attour in 2014 in their studies on synthetic water, which showed that there is no need to realize $\mathrm{pH}$ modifications for an efficient removal of phosphates. Furthermore, Nassef and Inan reported that the highest removal percentages are obtained at an optimal $\mathrm{pH}$ of 8 . However, the results of this study reflect that at a neutral $\mathrm{pH}$ there is minimum difference.

In the case of nitrogen, the data presented in Figure 2 and Table 3 indicate that the highest efficiency was obtained at an acidic $\mathrm{pH}$ of 6 , reaching a value of $27 \%$, while at a natural $\mathrm{pH}$ of $7.5 \mathrm{a}$ value of $23 \%$ was obtained. Inan reported something similar: at a $\mathrm{pH}$ of 8 , an efficiency of $21 \%$ was achieved. Furthermore, Devlin obtained a total nitrogen removal efficiency that ranged from $10 \%$ to $20 \%$ with an effluent the $\mathrm{pH}$ of which ranged from 7 to 7.9 .

b)

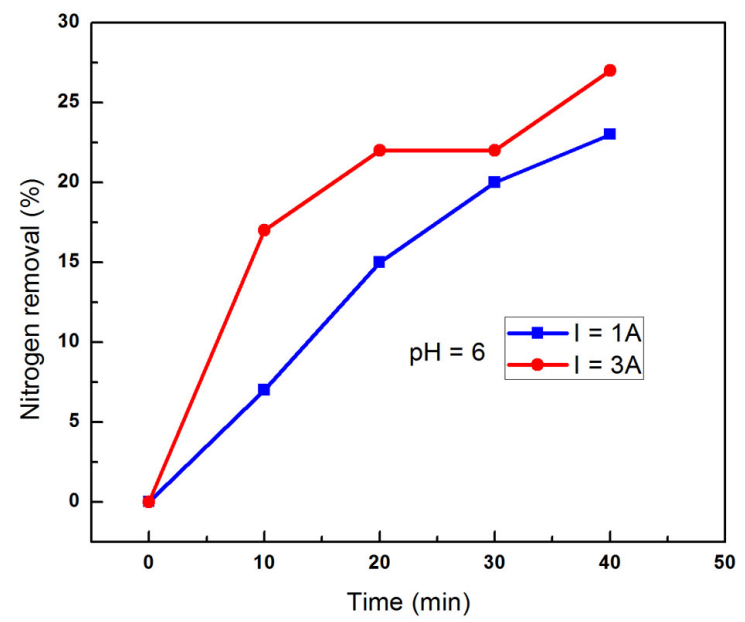

c)

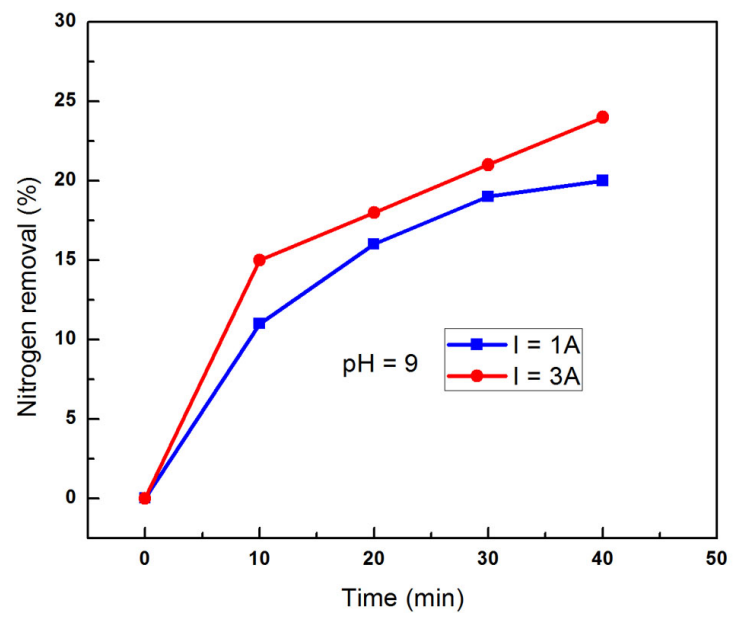

Figure 2. Nitrogen removal (\%) versus time.

Nitrogen $\mathrm{C}_{0}=62.63 \mathrm{mg} / \mathrm{l}$; a) $\mathrm{pH}=7.5$; b) $\mathrm{pH}=62$; c) $\mathrm{pH}=9$ 
a)

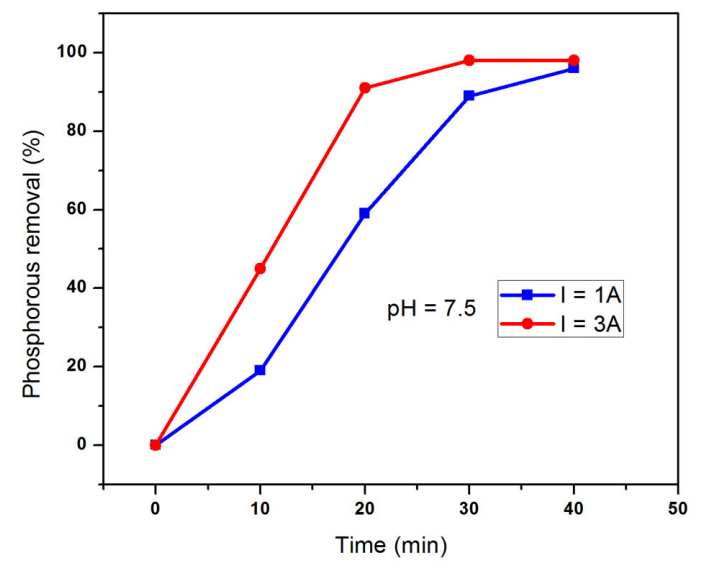

b)

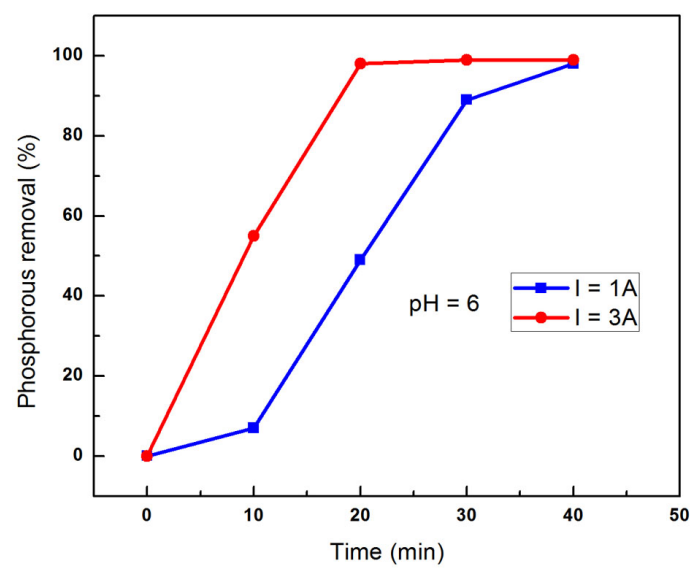

c)

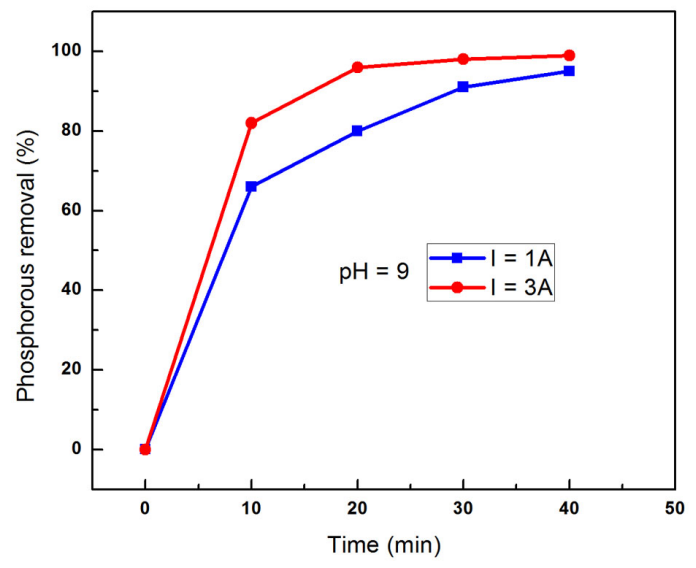

Figure 3. Phosphorus removal (\%) versus time.

Phosphorus $\mathrm{C}_{0}=8.06 \mathrm{mg} / \mathrm{l}$; a) $\mathrm{pH}=7.5$; b) $\mathrm{pH}=6$; c) $\mathrm{pH}=9$

\section{RESULTS}

Table 3 below gives the results obtained from the nitrogen and phosphorus experimental design, from which the relationship between the three independent variables $\left(\mathrm{x}_{1}, \mathrm{x}_{2}\right.$, and $\left.\mathrm{x}_{3}\right)$ and their influence on the response variable is determined. The quadratic regression model of the removal percentage of nitrogen $\left(\mathrm{y}_{1}\right)$ and phosphorus $\left(\mathrm{y}_{2}\right)$ is given by equations 11 and 12 .

Nitrogen:

$$
\begin{gathered}
y_{1}=17.2188+3.41667 \mathrm{x}_{1}+10.35 \mathrm{x}_{2}- \\
-1.125 \mathrm{x}_{3}-1.6875 \mathrm{x}_{2}^{2}+ \\
3.625 \mathrm{x}_{3}{ }^{2}-0.95 \mathrm{x}_{1} \mathrm{x}_{2}-1.375 \mathrm{x}_{1} \mathrm{x}_{3}-1.725 \mathrm{x}_{2} \mathrm{x}_{3}
\end{gathered}
$$

Phosphorus:

$$
\begin{gathered}
y_{2}=83.6458+18.3333 \mathrm{x}_{1}+51.2 \mathrm{x}_{2}+ \\
+14.125 \mathrm{x}_{3}-33.375 \mathrm{x}_{2}{ }^{2}+ \\
13.875 \mathrm{x}_{3}{ }^{2}-16.0 \mathrm{x}_{1} \mathrm{x}_{2}-8.125 \mathrm{x}_{1} \mathrm{x}_{3}-22.125 \mathrm{x}_{2} \mathrm{x}_{3}
\end{gathered}
$$

Table 4 gives the results of ANOVA, where a correlation coefficient $\mathrm{R}^{2}$ was found: 0.9167 for nitrogen and 0.9395 for phosphorus. The proposed statistical model explains $91.67 \%$ and $93.95 \%$ of the variability in the nitrogen and phosphorus removal ratio, respectively, indicating a good fit of the model.

In the case of nitrogen, it was also determined that current intensity and time are the most significant variables on the response variable, while for phosphorus the three factors had a significant effect at a level of $\alpha=0.05$. This is confirmed in Figures 4 and 5, where the main effects on the response variable are observed.

Similarly, the response surface graphs from the statistical analysis are shown in figures 6 and 7 , where the variation in the percentage of the nitrogen and phosphorus removal due to the effects of the intensity of the current intensity, time, and $\mathrm{pH}$ can be observed. 
Table 3. Experimental design with the response variable removal (\%) of nitrogen and phosphorus

\begin{tabular}{|c|c|c|c|c|c|}
\hline \multirow{3}{*}{ \# Exp. } & \multicolumn{3}{|c|}{ Factors } & \multicolumn{2}{|c|}{ Removal (\%) } \\
\hline & Current intensity (A) & Time (min) & $\mathrm{pH}$ & Nitrogen & Phosphorus \\
\hline & $X_{1}$ & $X_{2}$ & $X_{3}$ & $y_{1}$ & $y_{2}$ \\
\hline 1 & 1 & 10 & 7.5 & 11 & 19 \\
\hline 2 & 1 & 20 & 7.5 & 16 & 59 \\
\hline 3 & 1 & 30 & 7.5 & 16 & 89 \\
\hline 4 & 1 & 40 & 7.5 & 21 & 96 \\
\hline 5 & 1 & 10 & 6 & 7 & 7 \\
\hline 6 & 1 & 20 & 6 & 15 & 49 \\
\hline 7 & 1 & 30 & 6 & 20 & 89 \\
\hline 8 & 1 & 40 & 6 & 23 & 98 \\
\hline 9 & 1 & 10 & 9 & 11 & 66 \\
\hline 10 & 1 & 20 & 9 & 16 & 80 \\
\hline 11 & 1 & 30 & 9 & 19 & 91 \\
\hline 12 & 1 & 40 & 9 & 20 & 95 \\
\hline 13 & 3 & 10 & 7.5 & 12 & 45 \\
\hline 14 & 3 & 20 & 7.5 & 17 & 91 \\
\hline 15 & 3 & 30 & 7.5 & 18 & 98 \\
\hline 16 & 3 & 40 & 7.5 & 23 & 98 \\
\hline 17 & 3 & 10 & 6 & 17 & 55 \\
\hline 18 & 3 & 20 & 6 & 22 & 98 \\
\hline 19 & 3 & 30 & 6 & 22 & 99 \\
\hline 20 & 3 & 40 & 6 & 27 & 99 \\
\hline 21 & 3 & 10 & 9 & 15 & 82 \\
\hline 22 & 3 & 20 & 9 & 18 & 96 \\
\hline 23 & 3 & 30 & 9 & 21 & 98 \\
\hline 24 & 3 & 40 & 9 & 24 & 99 \\
\hline
\end{tabular}

Table 4. ANOVA for nitrogen and phosphorus

\begin{tabular}{|c|c|c|c|c|c|c|}
\hline & Variation Source & Sum Sq. & DF & Mean Sq. & F value & $\mathrm{P}$ Value \\
\hline \multirow{11}{*}{$\begin{array}{l}z \\
\text { U్ } \\
\text { O } \\
\underline{\underline{Y}} \\
\bar{z}\end{array}$} & $\mathrm{x}_{1}:$ Current intensity $(\mathrm{A})$ & 70.0417 & 1 & 70.0417 & 24.60 & 0.0002 \\
\hline & $\mathrm{x}_{2}$ : Time $(\min )$ & 357.075 & 1 & 357.075 & 125.44 & 0.0000 \\
\hline & $\mathrm{x}_{3}: \mathrm{pH}$ & 5.0625 & 1 & 5.0625 & 1.78 & 0.2022 \\
\hline & $x_{1} x_{2}$ & 3.00833 & 1 & 3.00833 & 1.06 & 0.3202 \\
\hline & $\mathrm{x}_{1} \mathrm{x}_{3}$ & 7.5625 & 1 & 7.5625 & 2.66 & 0.1239 \\
\hline & $\mathrm{x}_{2}^{2}$ & 3.375 & 1 & 3.375 & 1.19 & 0.2934 \\
\hline & $x_{2} x_{3}$ & 6.6125 & 1 & 6.6125 & 2.32 & 0.1483 \\
\hline & $\mathrm{x}_{3}^{2}$ & 17.5208 & 1 & 17.5208 & 6.15 & 0.0254 \\
\hline & Total Error & 42.7 & 15 & 2.84667 & & \\
\hline & Total & 512.958 & 23 & & & \\
\hline & \multicolumn{6}{|l|}{$R^{2}=91.6757 \%$ Adj $R^{2}=87.2361 \%$} \\
\hline \multirow{11}{*}{ 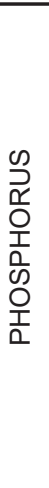 } & $\mathrm{x}_{1}$ : Current intensity $(\mathrm{A})$ & 2016.67 & 1 & 2016.67 & 30.65 & 0.0001 \\
\hline & $\mathrm{x}_{2:}$ Time $(\min )$ & 8738.13 & 1 & 8738.13 & 132.79 & 0.0000 \\
\hline & $\mathrm{x}_{3:} \mathrm{pH}$ & 798.063 & 1 & 798.063 & 12.13 & 0.0033 \\
\hline & $x_{1} x_{2}$ & 853.333 & 1 & 853.333 & 12.97 & 0.0026 \\
\hline & $x_{1} x_{3}$ & 264.062 & 1 & 264.062 & 4.01 & 0.0636 \\
\hline & $\mathrm{x}_{2}^{2}$ & 1320.17 & 1 & 1320.17 & 20.06 & 0.0004 \\
\hline & $x_{2} x_{3}$ & 1087.81 & 1 & 1087.81 & 16.53 & 0.0010 \\
\hline & $x_{3}^{2}$ & 256.688 & 1 & 256.688 & 3.90 & 0.067 \\
\hline & Total Error & 987.075 & 15 & 65.805 & & \\
\hline & Total & 16322.0 & 23 & & & \\
\hline & \multicolumn{6}{|l|}{$R^{2}=93.9525 \%$ Adj $R^{2}=90.7271 \%$} \\
\hline
\end{tabular}




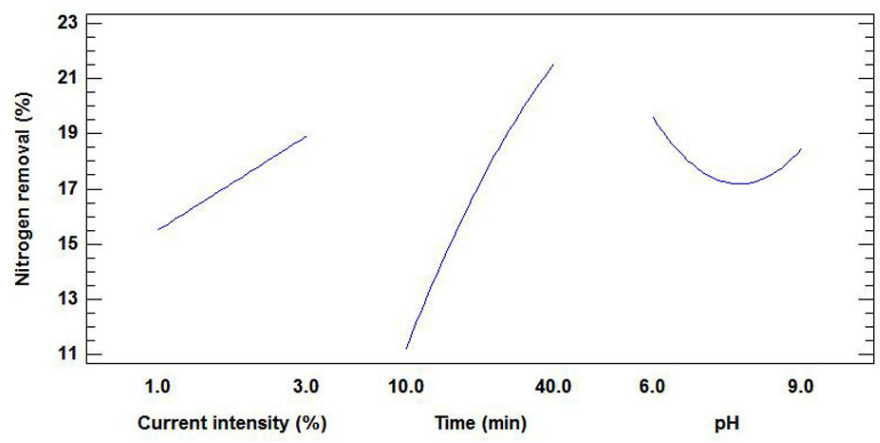

Figure 4. Graph of the main effects for the nitrogen removal

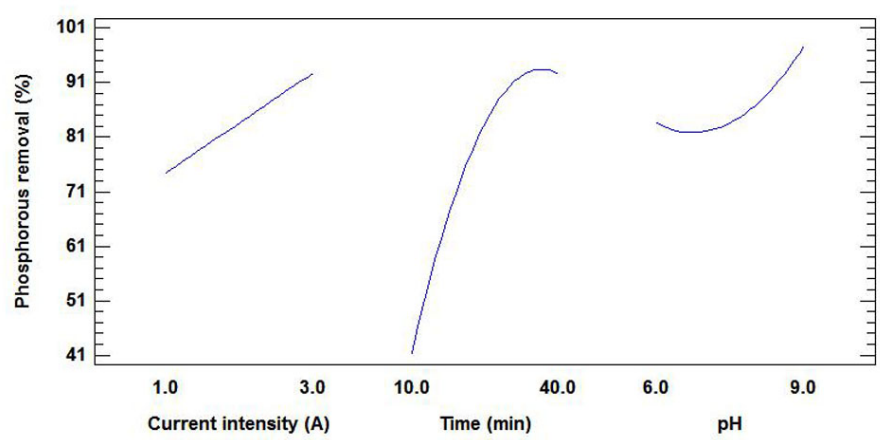

Figure 5. Graph of main effects for the phosphorus removal

a)
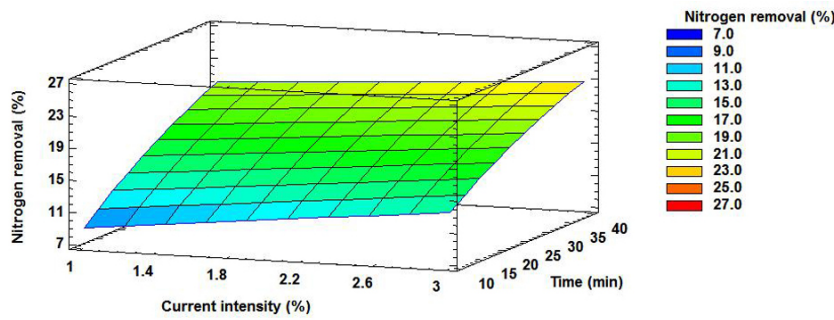

b)
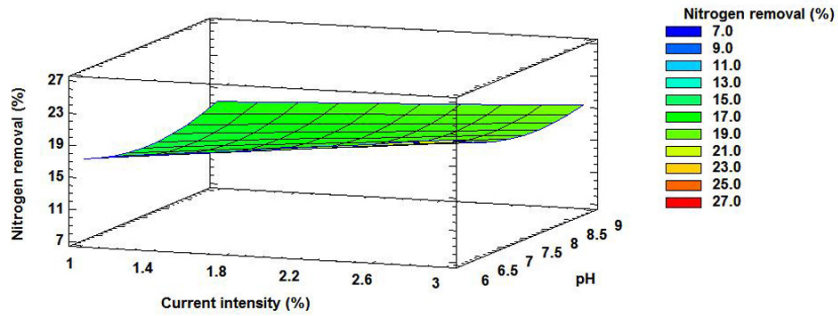

c)
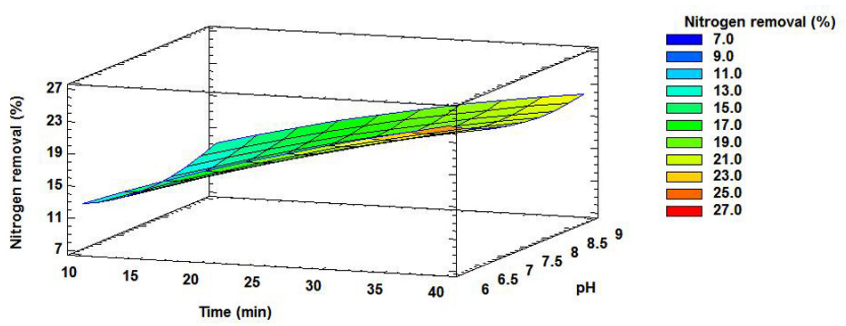

Figure 6. Response surface graphs for the percentage of nitrogen removal; 6a) current intensity and time; $6 \mathrm{~b}$ ) current intensity and $\mathrm{pH}$; 6c) time and $\mathrm{pH}$ 
a)

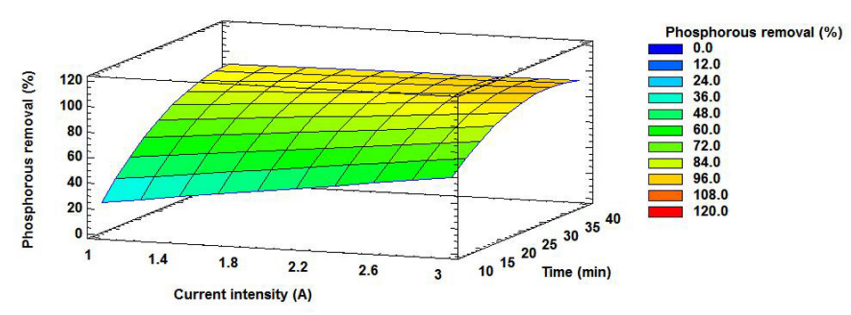

b)

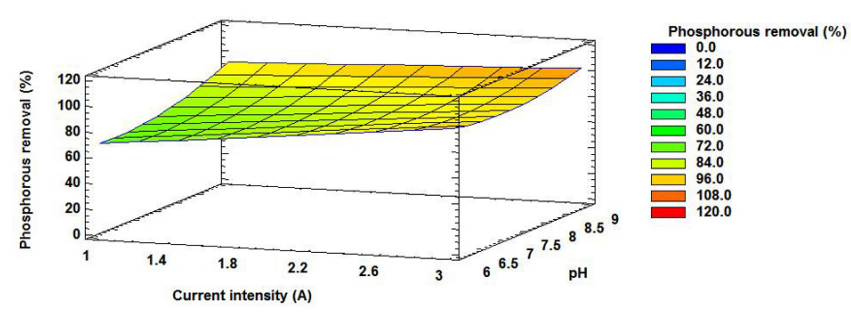

c)

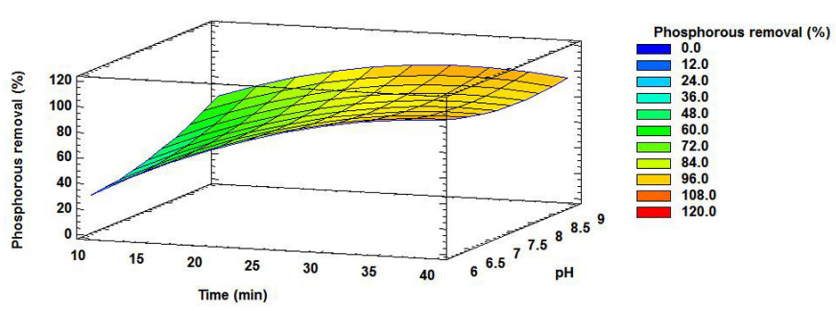

Figure 7. Response surface graphs for the percentage of phosphorus removal; 7a) current intensity and time;

7b) current intensity and $\mathrm{pH} ; 7 \mathrm{c}$ ) time and $\mathrm{pH}$

\section{CONCLUSIONS}

The analysis of the nitrogen experimental design indicates that time and current intensity were the most influential variables in the process, while the effect of $\mathrm{pH}$ was not significant with respect to the response variable (percentage of nitrogen removal), exhibiting a correlation coefficient $\mathrm{R}^{2}$ of $91.67 \%$. With respect to phosphorus, the results indicate that the three variables: time, current intensity, and $\mathrm{pH}$, were significant in the process, where a correlation coefficient $\mathrm{R}^{2}$ of $93.95 \%$ was obtained. The highest nitrogen removal percentage was $27 \%$ under acidic conditions at a $\mathrm{pH}$ of 6 and 3 amps and a treatment time of 40 minutes. However, at the wastewater natural $\mathrm{pH}$ of 7.5 , the efficiency was also close to $24 \%$. The phosphorus removal values were very high, approximately $98 \%$ and $99 \%$, with a current intensity of 3 amps, a treatment time of 40 minutes, and a modified $\mathrm{pH}$ of 6 . It should be noted that at a natural and basic $\mathrm{pH}$, practically the same values $(98 \%$ removal) were obtained. Regarding the treatment time, it can be determined that after 30 minutes, very similar values are reached for the removal of both nitrogen and phosphorus. This research validated the ability of the electrocoagulation process to remove phosphorus and nitrogen from domestic wastewater, which is an additional benefit, because it allows the elimination of parameters from the primary reactor compared with conventional biological processes, where additional compartments (either anaerobic or anoxic) have to be installed to accomplish this task.

\section{Acknowledgements}

To the Institute of Scientific Research of Universidad de Lima [Lima University], for fully supporting the development of this study; and to the Research Center in Treatment of Wastewater and Hazardous Waste of the Universidad Nacional de Ingeniería [National University of Engineering] for their collaboration in the project.

\section{REFERENCES}

1. Attour A., Touati M., Tlili M., Ben Amor M., Lapicque F., Leclerc J-P. 2014. Influence of operating parameters on phosphate removal from water by electrocoagulation using aluminum electrodes. Separation and Purification Technology, 123, 124-129. DOI: 10.1016/j.seppur.2013.12.030. 
2. Bouamra F., Drouiche N., Ahmed D.S., Lounic H. 2012. Treatment of water loaded with orthophosphate by electrocoagulation. Procedia Engineering, 33, 155-162.DOI:10.1016/j.proeng. 2012.01.1188.

3. Can O.T. 2014. COD removal from fruit-juice production wastewater by electrooxidation electrocoagulation and electro-Fenton process. Desalination and Water Treatment, 52(1-3), 65-73. DOI:10.108 0/19443994.2013.781545.

4. Chen G. 2004. Electrochemical technologies in wastewater treatment. Separation and Purification Technology, 38, 11-41. DOI: http://dx.doi. org/10.1016/j.seppur.2003.10.006

5. Elnenay A., Nassef E., Malash G., Magrid M. 2016. Treatment of drilling fluids wastewater by electrocoagulation. Egyptian Journal of Petroleum, 26, 203-208. DOI:10.1016/j.ejpe.2016.03.005.

6. Emamjomeh M.M., Sivakumar M. 2019. Denitrification using a monopolar electrocoagulation/ flotation (ECF) process. Journal of Environmental Management, 91, 516-522. DOI: 10.1016/j. jenvman.2009.09.020.

7. Inan H., Alaydin E. 2014. Phosphate and nitrogen removal by iron produced in electrocoagulation reactor. Desalination and Water Treatment, 52(7-9), 1396-1403, DOI: 10.1080/19443994.2013.787950.

8. Khandegar V., Saroha A. 2013. Electrocoagulation for the treatment of textile industry effluent-A review. Journal of Environmental Management, 128, 949-963. DOI: 10.1016/ j.jenvman.2013.06.043.

9. Kobya M., Hiz H., Senturk E., Aydiner C., Demirbas E. 2006. Treatment of potato chips manufacturing wastewater by electrocoagulation. Desalination, 190(1-3), 201-211.DOI:10.1016/j. desal.2005.10.006.

10. Koukkanen V., Koukkanen T., Ramo U., Lassia U., Roininen J. 2015. Removal of phosphate from wastewaters for further utilization using electro-coagulation with hybrid electrodes-Techno-economic studies. Journal of Water Process Engineering, 8, 50-57. DOI:10.1016/j.jwpe.2014.11.008.

11. Li X., Song J., Guo J., Wang Z., Feng Q. 2011. Landfill leachate treatment using electrocoagulation. Procedia Environmental Sciences, 10, 1159-1164. DOI:10.1016/j.proenv.2011.09.185.

12. Mouedhen G., Feki M., Wery M., Ayedi H.F. 2008. Behavior of aluminum electrodes in electrocoagulation process. Journal of Hazardous Materials, 150(1), 124-135. DOI:10.1016/j.jhazmat. 2007.04.090.

13. Muñoz-Paredes J.F., Ramos-Ramos M. 2014. Reactores discontinuos secuenciales: Una tecnología versátil en el tratamiento de aguas residuales. Ciencia e Ingeniería Neogranadina, 24 (1), 49-66. DOI: $10.18359 /$ rcin.7

14. Nassef E. 2012. Removal of phosphorous compounds by electrochemical technique. Engineering Science and Technology: An International Journal, 2(3), 403-407. Recuperado de http://www.estij.org/ papers/vol2no32012/7vol2no3.pdf

15. Orssatto F., Tavares M.H.F., Silva F.M., Eyng E., Fleck L. 2018. Optimization of nitrogen and phosphorus removal from pig slaughterhouse and packing plant wastewater through electrocoagulation in a batch reactor. Ambiente \& Água, 13(5), 1-10. DOI: http://dx.doi.org/10.4136/ambi-agua.2233.

16. Omwene P.I., Kobya M. 2018. Treatment of domestic wastewater phosphate by electrocoagulation using Fe and Al electrodes: A comparative study DOI: 10.1016/j.psep.2018.01.005.

17. Omwene P.I., Kobya M., Can O.T.2018. Phosphorus removal from domestic wastewater in electrocoagulation reactor using aluminium and iron plate hybrid anodes. Ecological Engineering, 123, 65-73. https:// doi.org/10.1016/j.ecoleng.2018.08.025.

18. Piña M., Martín A., Gonzáles C., Prieto F., Guevara A., García J. 2011. Revisión de variables de diseño y condiciones de operación en la electrocoagulación. Revista Mexicana de Ingeniería Química, 10(2), 257-271. Access: http://www. scielo.org.mx/scielo.php?script $=$ sci_arttext\&pid $=$ S1665-27382011000200010

19. Rahimi Y., Torabian A., Mehrdadi N., Shamoradi B. 2011. Simultaneous nitrification-dentrification and phosphorus removal in a fixed bed sequencing batch reactor (FBSBR).Journal of Hazardous Materials, 185(2-3), 852-857. DOI: 10.1016/j. jhazmat.2010.09.098.

20. Ryan Devlin T., Kowalski M.S., Pagaduan E., Zhang X., Wei V., Oleszkiewicz J.A. 2018. Electrocoagulation of raw wastewater using aluminum, iron, and magnesium electrodes. Journal of Hazardous Materials (2018). https://doi.org/10.1016/j. jhazmat.2018.10.017.

21. Taufer G., Müller C. S., Hilgemann M. 2016. Phosphorus and nitrogen removal in the dairy industry effluent by electrocoagulation. Scientia Plena, 12(9), 1-6. DOI: 10.14808/sci.plena.2016.097202.

22. Thapa A., Rahman S., Borhan M. 2015. Remediation of feedlot nutrients runoff by electrocoagulation process. American Journal of Environmental Sciences, 11(5), 366-379. DOI: 10.3844/ajessp. 2015.366.379.

23. Tian Y., He W., Liang D., Yang W., Logan B.E., Ren N. 2018. Effective phosphate removal for advanced water treatment using low energy, migration electric-field assisted electrocoagulation. Water Research, 138, 129-136. DOI: 10.1016/j. watres.2018.03.037.

24. Yehya T., Chafi M., Balla W., Vial C., Esadki A., Gourich B. 2014. Experimental analysis and modeling of denitrification using electrocoagulation process. Separation and Purification Technology, 132, 644-654. DOI: 10.1016/j.seppur.2014.05.022.

25. Zhang X., Lin H., Hu B. 2016. Phosphorus removal and recovry from dairy manureby electrocoagulation. RSC Advances, 6, 57960-57968. DOI: 10.1039/C6RA06568F. 